\title{
PENGUKURAN VARIABEL PROSES PADA QUADRUPLE EFFECT EVAPORATION DI PABRIK GULA
}

\section{MEASUREMENT OF PROCESS VARIABLES ON EVAPORATION QUADRUPLE EFFECT IN SUGAR FACTORIES}

\author{
J oko Hanuranto, Anwar Mustafa \\ Pusat Teknologi Industri Proses \\ Deputi Teknologi Industri Rancang Bangun \& Rekayasa \\ Badan Pengkajian dan Penerapan Teknologi \\ Gedung Teknologi 2 Lt. 3, Kompleks PUSPIPTEK, Serpong \\ Email : hanuraniputri@yahoo.com \\ awestafa@yahoo.com.
}

\begin{abstract}
Abstrak
Untuk meningkatkan efisiensi pabrik gula, tingkat kebutuhan steam serta pengaruh kondisi transfer panas permukaan pada stasiun penguapan perlu dianalisa. Sistem penguapan yang banyak digunakan pada pabrik gula baru adalah penguap quadruple effect evaporator. Hal ini dilakukan karena efisiensi proses penguapan di stasiun penguapan akan mempengaruhi efisiensi dari keseluruhan proses dalam proses produksi gula. Analisis data yang diperoleh dengan mengukur variabel proses penguapan di stasiun meliputi laju aliran getah, suhu, tekanan, dan pengambilan sampel periodik untuk menganalisis fraksi aliran getah padat dalam jus.
\end{abstract}

Kata kunci: stasiun penguapan - Quadruple Effect Evaporator, Pabrik Gula

\begin{abstract}
To improve the efficiency of sugar mills, the steam demand levels as well as the influence of the heat transfer surface conditions on evaporation station needs analysis. The new sugar plan commontly use quadruble effect Evaporation system This is done because the efficiency of the evaporation process on evaporation station will affect the efficiency of the overall process in the sugar production process. Analysis of data obtained by measuring the evaporation process variables at stations covering sap flow rate, temperature, pressure, and periodic sampling to analyze the fraction of sap flow of solids in the juice.
\end{abstract}

Keywords : Evaporation station- Quadruple Effect Evaporation, Pabrik Gula

Diterima (received) : 13 Januari 2013, Direvisi (reviewed) : 22 Januari 2013,

Disetujui (accepted) : 18 Pebruari 2013

\section{PENDAHULUAN}

Pasar global mengakibatkan industri gula masuk ke persaingan pasar yang semakin ketat, sehingga pabrik gula harus dapat menekan biaya proses untuk dapat mencapai target harga jual produk yang dapat bersaing. Selama ini biaya bahan baku tinggi menjadi alasan utama terhadap tingginya harga gula, sehingga kondisi proses produksi yang kurang efisiens menjadi terlupakan. Dengan kenyataan bahwa komoditi gula berperan penting dalam menjaga stabilitas ekonomi nasional, maka meningkatkan tingkat efisiensi proses produksi adalah salah satu cara untuk memotong biaya dan mempertahankan profitabilitas perusahaan. Pengurangan biaya produksi dapat dicapai dengan cara memperbaiki ketidakefisienan yang terdeteksi dari proses produksi, dan melalui sistem koordinasi serta kontrol yang baik terhadap proses operasi pabrik, akan dapat menjamin produksi gula secara maksimum. 
Untuk melihat dan memperbaiki ketidakefisienan yang terjadi pada stasiun penguapan, dalam tulisan ini, dilakukan pengamatan dan analisis sejumlah variabel dan parameter pada stasiun penguapan multiple effect (Quadtuple evaporator). Variabel proses seperti laju alir massa nira, suhu, tekanan dan berat jenis, diukur dengan sistem pengamatan langsung pada indikator yang ada pada peralatan tersebut serta pengambilan sampel langsung dan juga dengan data digital untuk melihat time data record. Diharapkan analisis ini memiliki potensi aplikasi praktis pada penerapan dilapangan dalam kerangka penghematan energi pada proses produksi gula.
Skema stasiun penguapan yang menganalisa sistem empat efek (quadruple evaporator) ditunjukkan pada Gambar. 1.

Kondisi peralatan dan hal hal yang berkaitan dengan pengamatan adalah sebagai berikut ${ }^{1}$

a. Pada analisis ini, luas pertukaran panas setiap efek adalah $1500 \mathrm{~m}^{2}$ kecuali efek keempat yang memiliki luas $1.350 \mathrm{~m}^{2}$.

b. Uap pemanasan yang masuk dalam efek pertama pada sekitar $110^{\circ} \mathrm{C}$.

c. Ketinggian nira yang mendidih dalam setiap efek dikendalikan dengan memanipulasi aliran nira keluar. Data Level Transmitter menunjukkan bahwa ketinggian cairan nira yang mendidih dalam setiap efek memiliki keragaman yang sempit.

\section{BAHAN DAN METODE}

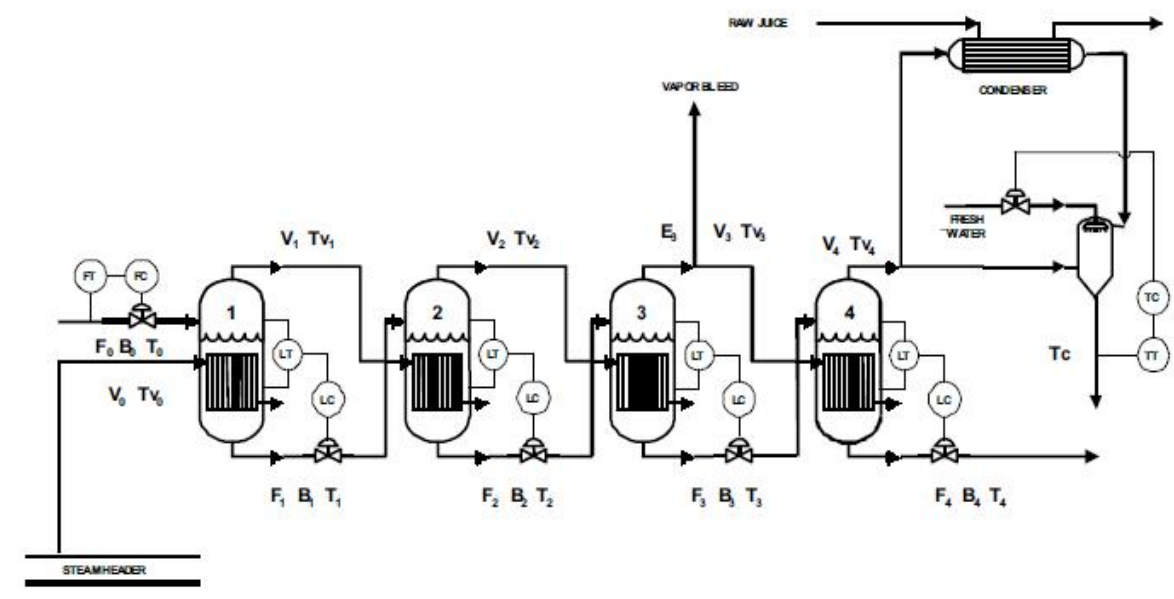

Gambar 1.

Flow Diagram Proses Penguapan Nira Dengan Quadruple Effect

a. Untuk analisis digunakan neraca masa energi dalam kondisi steady state.

b. Suhu di barometrik kondensor dikendalikan agar gangguan kevakuman dalam efek terakhir dapat berkurang.

c. Aliran nira yang diumpankan ke efek pertama diukur dengan flow meter dan aliran uap di bleeding dari efek ketiga.

d. Untuk setiap efek, suhu cairan nira yang mendidih dan uap diukur dengan thermo resistances Pt-100.

e. Sampel nira masuk (feed) dan nira kental keluar (produk) diambil setiap 5 menit.

f. Sampel dianalisis dengan refraktometer untuk mengevaluasi konsentrasinya yang dinyatakan sebagai derajat Brix.

g. Jumlah variabel yang diukur ada 14 point (2 aliran, 10 suhu, dan 2 komposisi)

h. Setelah operasi proses pabrik gula berjalan dalam kondisi steady state, beberapa langkah utama yang dilakukan adalah sebagai berikut:

i. Menunggu sampai semua variabel yang akan diukur stabil pada basis waktu yang ditetapkan.

j. Pengambilan sampel untuk analisa masukan dan produk. Durasi sampling sekitar 2 jam.

k. Verifikasi pengoperasian Level control loop untuk memastikan proses dalam kondisi steady state.

Selama pengujian, gangguan apapun yang dapat mempengaruhi kinerja dari peralatan itu dihindari semaksimal mungkin, hal ini tidak selalu mungkin dilakukan karena struktur yang kompleks stasiun penguapan itu sendiri. Misalnya, variabel input kadangkadang mengalami perubahan drastis yang disebabkan oleh kondisi peralatan lain atau oleh operator. Data yang dihasilkan berasal 
dari tiga jenis tes yang dilakukan, sesuai dengan hari yang berbeda dari siklus kerja peralatan penguapan. Setiap tes dikaitkan dengan tingkat fouling pada permukaan pertukaran panas.

Ada tiga pengujian/pengamatan yang dilakukan sebagai berikut :

\section{a. Pengamatan (Test) A}

Uji ini dilakukan saat peralatan beroperasi pada hari ketiga dari 7 hari siklus kerja, hal ini dilakukan berkaitan dengan kondisi fouling yang moderat pada permukaan pertukaran panas.

b. Pengujian/ Pengamatan Tests B

Uji B dilakukan dengan peralatan evaporator yang yang telah dibersihkan, hal ini berkaitan dengan fouling yang paling minimal pada permukaan perpindahan panas..

c. Pengujian/Pengamatan $\mathrm{C}$
Uji C (2 $1 / 2$ jam uji) dilakukan pada hari kerja ke 6 , ketika evaporator memiliki jumlah fouling tinggi pada permukaan perpindahan panas.

\section{HASIL DAN PEMBAHASAN}

\section{Hasil dan analisis (Test) A}

Dari data hasil pengamatan, besaran temperatur tidak menunjukkan tren tetapi menyajikan besarnya variabilitasnya, artinya besaran temperatur yang teramati mempunyai deviasi standar dari nilai atas dan nilai bawah sebagaimana ditunjukkan pada Tabel 1.

Tabel 1.

Perhitungan Statistic Variability Stasioner Dari Data Temperatur, Aliran Uap Dan Fraksi Padat

(Test A)

\begin{tabular}{crrrr} 
Variabel & Nilai Min. & Nilai Maks. & \multicolumn{1}{c}{ Rata $^{2}$} & Standard Deviasi \\
\hline To & 108.9 & 114.7 & 111.8 & 1.5 \\
Tvo & 106.4 & 119.2 & 110.2 & 3.5 \\
T1 & 96.3 & 101.0 & 89.3 & 1.0 \\
Tv1 & 85.5 & 99.8 & 96.8 & 1.2 \\
T2 & 82.1 & 90.9 & 88.4 & 1.3 \\
Tv2 & 82.1 & 89.1 & 85.6 & 1.6 \\
T3 & 74.2 & 81.2 & 77.5 & 1.7 \\
Tv3 & 70.0 & 79.4 & 74.2 & 2.0 \\
T4 & 53.3 & 60.3 & 57.4 & 1.1 \\
Tv4 & 52.8 & 56.1 & 54.3 & 1.0 \\
Tc & 33.2 & 38.4 & 36.0 & 1.1 \\
E3 & 10.3 & 17.5 & 12.9 & 1.5 \\
Bo & 20.3 & 24.0 & 22.3 & 1.1 \\
\hline
\end{tabular}

Grafik variabel yang diukur secara digital selama uji tersebut disajikan pada Gambar. 1,2 , dan 3 .

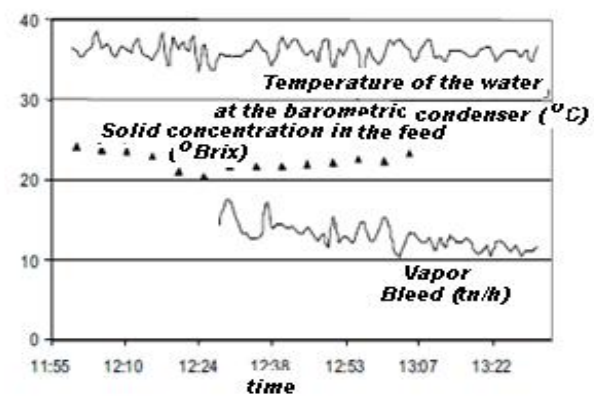

Gambar 1.

Digital Data R ecord Konsentrasi Solid Di Feed (Bo), Uap Bleeding ( E3) Dan
Temperatur Air Pendingin Di Kondensor Barometric (Tc) (Test A)

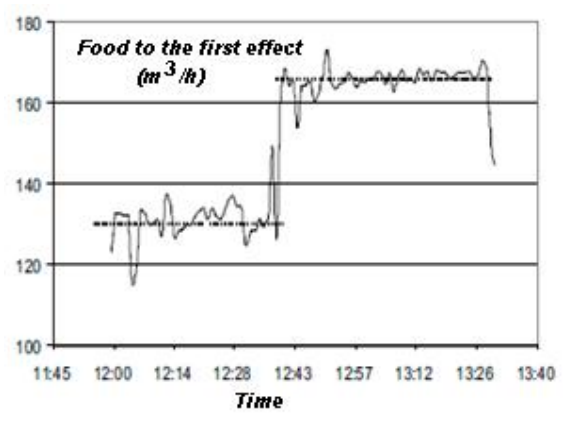

Gambar 2.

Digital Data R ecord Aliran Nira Masuk Pada Efek Pertama (Feed) (Test A) 


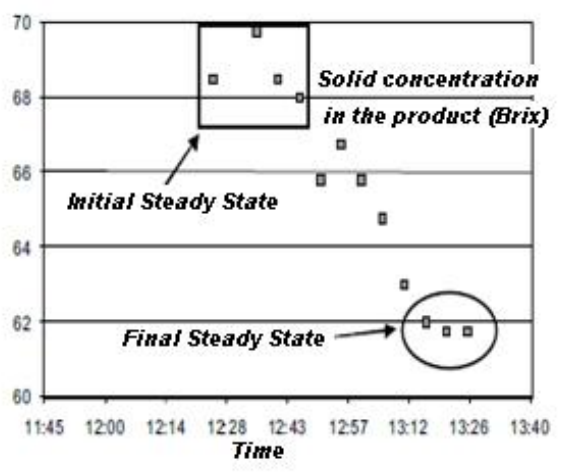

Gambar 3.

Digital Data Record Konsentrasi Solid Pada Nira Kental (Test A)

Seperti yang terlihat pada Gambar.1, aliran uap bleeding menunjukkan kecenderungan moderat (pada tingkat kepercayaan 95\%), dengan tidak menunjukkan gejolak/ perubahan yang drastis. Selama pengujian operator secara drastis meningkatkan aliran nira jernih (pre evaporated) untuk diumpankan ke evaporator pertama (lihat Gambar. 2). Hal ini menyebabkan penurunan konsentrasi solid pada produk seperti ditunjukkan pada Gambar. 3 di mana kondisi steady state sebelum dan setelah terjadinya gangguan dapat diidentifikasi. Namun perubahan aliran nira secara drastis yang diumpankan tidak menunjukkan pengaruh yang signifian pada variabilitas dari temperature dan laju uap bleeding. Informasi statistik tentang konsentrasi solid pada produk nira kental (B4) dan nira jernih yang diumpankan ke efek pertama $\left(\mathrm{F}_{\mathrm{o}}\right)$ disajikan pada Tabel 2.

Tabel 2.

Perhitungan Statistik Variabel Non Stasioner ( Test A)

\begin{tabular}{ccccc} 
Variabel & \multicolumn{2}{c}{ Kondisi Awal } & \multicolumn{2}{c}{$\begin{array}{c}\text { Kondisi } \\
\text { Steady State }\end{array}$} \\
\hline & Rata $^{2}$ & $\begin{array}{c}\text { Standard } \\
\text { Deviasi }\end{array}$ & Rata $^{2}$ & Standard Deviasi \\
Fo $\left(\mathrm{m}^{3}\right.$ /jam $)$ & 130.8 & 5.3 & 165.1 & 4.5 \\
B4 (o Brix) & 69.4 & 1.2 & 61.8 & 0.1 \\
\hline
\end{tabular}

\section{Hasil Dan Analisis Tests B and C}

Uji B dilakukan dengan peralatan evaporator yang telah dibersihkan. Kemudian, evaporator dianalisis pada kapasitas pertukaran panas tertinggi.

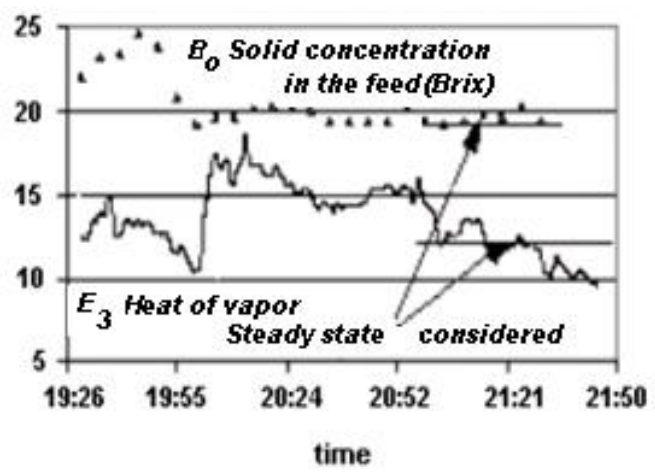

Gambar 4.

Digital Data Record Konsentrasi Solid Feed (Bo) Dan Uap Bleeding (E3) ( Test B)
Pada tahap pertama pengujian, beberapa perubahan dilakukan pada konsentrasi solid dari aliran umpan dan juga pada aliran uap bleeding dari efek ketiga. Waktu berlaku Uji B adalah sekitar 150 menit dan kondisi steady state diamati pada 60 menit terakhir seperti yang ditunjukkan pada Gambar 4 dan 5

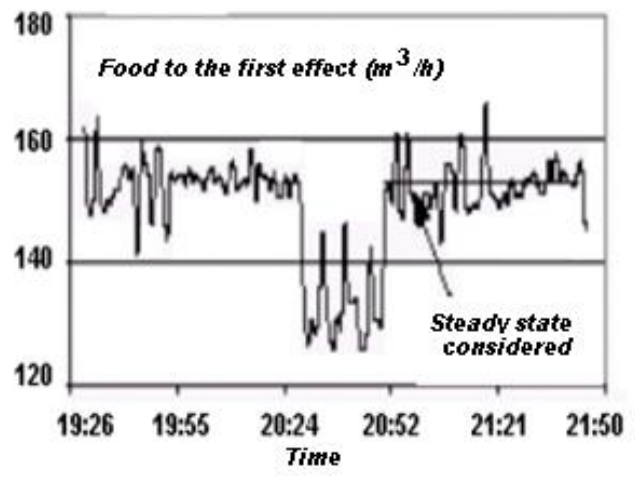

Gambar 5.

Digital Data Record Aliran Nira Masuk Pada Efek Pertama (Test B) 
Uji B dilakukan dengan peralatan evaporator yang telah dibersihkan. Kemudian, evaporator dianalisis pada kapasitas pertukaran panas tertinggi. Pada tahap pertama pengujian, beberapa perubahan dilakukan pada konsentrasi solid dari aliran umpan dan juga pada aliran uap bleeding dari efek ketiga. Waktu berlaku Uji B adalah sekitar 150 menit dan kondisi steady state diamati pada 60 menit terakhir seperti yang ditunjukkan pada Gambar 4 dan 5.

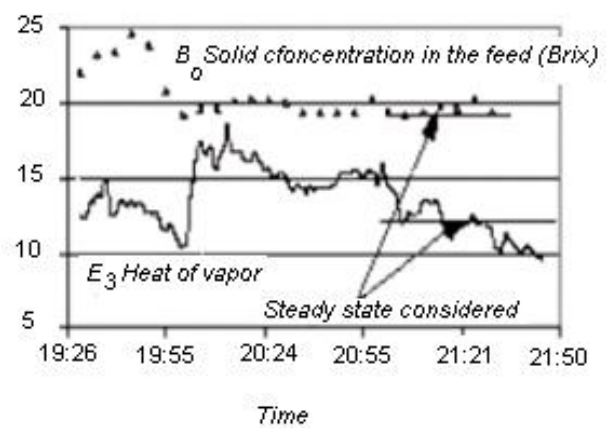

Gambar 4.

Digital Data Record Konsentrasi Solid Feed

(Bo) Dan Uap Bleeding (E3) ( Test B)

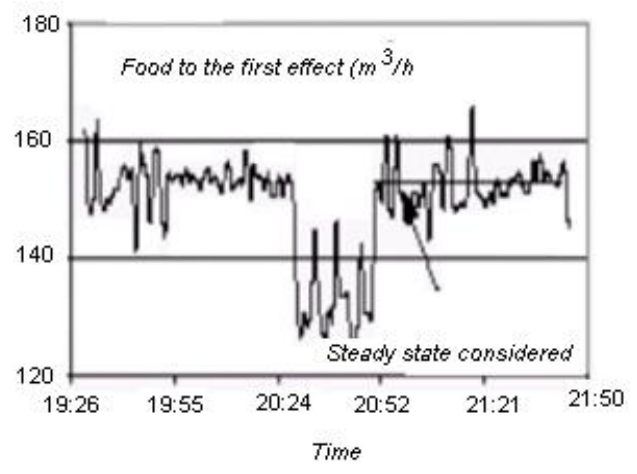

Gambar 5.

Digital Data Record Aliran Nira Masuk Pada Efek Pertama (Test B)

Uji C (2 $1 / 2$ jam uji ) terkait dengan hari kerja ke 6, ketika evaporator memiliki jumlah fouling tinggi pada permukaan perpindahan panas. Hasil Tes B dan C ditunjukkan pada Tabel 3.

Tabel 3.

Perhitungan Statistik Variabel Proses ${ }^{4)}$

\begin{tabular}{lrrrr} 
& \multicolumn{2}{c}{ Test B } & \multicolumn{2}{c}{ Test C } \\
\cline { 2 - 5 } Variable & Rata $^{2}$ & $\begin{array}{c}\text { Standard } \\
\text { Deviasi }\end{array}$ & \multicolumn{1}{c}{ Rata $^{2}$} & \multicolumn{2}{c}{$\begin{array}{c}\text { Standard } \\
\text { Deviasi }\end{array}$} \\
\hline To & 113.6 & 1.5 & 107 & 2 \\
Tvo & 113.9 & 1.5 & 110.8 & 2.8 \\
T1 & 99.3 & 1.2 & 99.8 & 1.9 \\
Tv1 & 97.7 & 1.2 & 97.1 & 2.1 \\
T2 & 89.9 & 1.1 & 88.2 & 2.5 \\
Tv2 & 86.8 & 1.5 & 85 & 2.7 \\
T3 & 78.6 & 1.3 & 78.1 & 2.1 \\
Tv3 & 81.9 & 1.3 & 75.4 & 1.2 \\
T4 & 59.4 & 1.7 & 57.8 & 2 \\
Tv4 & 56.1 & 0.8 & 57.8 & 2 \\
Tc & 33.8 & 0.4 & 39.1 & 1.4 \\
E3 & 12.4 & 1.8 & 10.8 & 1.3 \\
Bo & 19.6 & 0.3 & 29.5 & 1.1 \\
E3 & 151.8 & 5.1 & 155 & 4.5 \\
B4 & 64.6 & 0.9 & 62.9 & 0.9 \\
\hline
\end{tabular}

\section{Perhitungan laju aliran uap di evaporator}

Konsumsi steam merupakan variabel kunci dalam neraca energi pabrik gula, maka estimasi pengukuran variabel tersebut menjadi sangat penting. Dalam sistem yang diteliti, tidak ada aliran uap yang dapat diukur karena diameter pipa besar dan kurangnya panjang pipa lurus yang memungkinkan menggunakan flowmeters konvensional. Untuk itu, system pengukuran dengan variabel lain digunakan untuk menghitung aliran uap

Resolusi neraca masa dan energi dari quadruple effect menunjukkan estimasi perbedaan besaran aliran uap dari nilai rata- 
rata variabel yang diukur. Neraca masa energi, persamaan perpindahan panas, korelasi kimia fisik dan sifat termodinamika aliran dijelaskan dengan persamaan vectorial berikut:

$$
f(x, y)=0
$$

dimana,

$\mathrm{x}$ : input vektor dari variabel dan parameter, dan

$y$ : output vektor dari variabel dan parameter yang dihitung

Variabilitas dari variabel yang diukur akan mempengaruhi estimasi output. Matriks kovarian memiliki dominasi diagonal kuat yang menyiratkan hubungan yang lemah antara input. Dalam kondisi seperti ini, varians dari variabel yi dapat diperkirakan sebagai berikut ${ }^{5)}$ :

$\operatorname{var}\left(y_{\mathrm{i}}\right)=\sum_{j}\left(\frac{\partial y_{i}}{\partial x_{j}}\right)^{2} \operatorname{var}\left(x_{j}\right)$

Persamaan 2 menunjukkan ukuran dari ketidakpastian dalam perkiraan output. Kontribusi masing-masing pecahan $\mathrm{X}_{J}$ input variabilitas output yi dapat dihitung sebagai berikut:

$$
\omega_{j}=\frac{\left(\frac{\partial y_{i}}{\partial x_{j}}\right)^{2} \operatorname{var}\left(x_{j}\right)}{\operatorname{var}\left(y_{i}\right)} \quad \begin{array}{r}
\text { Analisis data } \\
\text { eksperimen }
\end{array}
$$

Tabel 4.

Perhitungan Nilai Dan Standard Deviasi Laju Uap Test B Dan Test C.

\begin{tabular}{ccccc}
$\begin{array}{c}\text { Aliran } \\
\text { (Ton/jam) }\end{array}$ & \multicolumn{2}{c}{ Test B (Peralatan Bersih) } & \multicolumn{2}{c}{ Test C (Fouling Maks.) } \\
Rata $^{2}$ & Standard deviasi & Rata $^{2}$ & Standard deviasi \\
\hline Vo & 26.1 & 1.6 & 21.5 & 1.5 \\
V1 & 29.5 & 1.5 & 23.2 & 1.3 \\
V2 & 31 & 1.5 & 25.3 & 1.2 \\
V3 & 18.9 & 2.1 & 16 & 1.5 \\
V4 & 20.1 & 2.1 & 18.1 & 1.5 \\
\hline
\end{tabular}

Kontribusi variabel fraksional yang diukur dengan varians aliran uap (steam) $V_{0}$ diringkas dalam Tabel 5. Kontribusi utama diberikan oleh komposisi aliran nira jernih masuk evaporator $\left(B_{0}\right)$. Perhatikan bahwa aliran umpan $\left(F_{o}\right)$ tidak memiliki signifikansi yang tinggi, terlepas dari adanya fluktuasi laju aliran yang signifikan. Hal ini juga terlihat bahwa kontribusi fraksional pada suhu yang diukur $T_{0}, T_{1}$ dan $T_{2}$ lebih besar dalam test $C$ dibandingkan test $B$ sebagai konsekuensi dari varians yang lebih tinggi dalam data pengamatan hasil dari uji $\mathrm{C}$. memungkinkan memperkirakan aliran uap dan variannya. Derivatif dari persamaan dievaluasi secara numerik sedangkan variannya dihitung dari time series dari pengukuran .Estimasi nilai laju uap dan standar deviasi tersebut disajikan pada Tabel. 4 untuk dua kondisi berikut:

a. Uji B : permukaan pertukaran bersih

b. Test $\mathrm{C}$ : fouling maksimum.

Estimasi laju uap ke efek pertama penting bagi pengaruhnya terhadap keseimbangan energi keseluruhan. Di sisi lain, estimasi laju uap yang meninggalkan efek terakhir ini juga penting karena aliran ini terkait dengan konsumsi air di kondensor barometrik. Laju uap yang dihasilkan di setiap unit evaporator menunjukkan ukuran kapasitas penguapan. Tabel 4 menunjukkan bahwa jumlah uap yang dihasilkan dalam efek di bawah kondisi bersih lebih besar, dengan tingkat signifikansi statistik 95\%, dibandingkan dengan uap yang dihasilkan pada tingkat maksimum fouling. Yang perlu di perhatikan bahwa dalam kedua uji tersebut, laju aliran nira jernih (praevaporator) adalah mirip, sedangkan konsentrasi padatan pada aliran produk (nira kental) lebih tinggi untuk evaporator bersih (lihat Tabel 3). 


\section{Estimasi Koefisien Heat-Transfer keseluruhan.}

Koefisien transfer panas menyeluruh dapat dievaluasi dari estimasi arus uap. Nilai koefisien transfer panas menyeluruh dengan dua uji yang berbeda kondisinya yakni pada permukaan bersih dan fouling maksimum, disajikan pada Tabel 7. Sebagai suatu referensi, koefisien diperkirakan dengan persamaan 4, ditampilkan dalam Tabel yang sama. Korelasi ini dikenal dengan baik di industri gula meskipun presisinya lemah (de Armas et al., 1994).

$$
\mathrm{Us}_{\mathrm{i}}=432 \frac{\mathrm{T}_{\mathrm{i}}}{\mathrm{B}_{\mathrm{i}}}
$$

Untuk efek i:

Tabel 6.

Koefisien Heat Transfer Keseluruhan ( Kcal/h m2 o C)- Test A

\begin{tabular}{ccccc}
\multirow{2}{*}{ Efek } & \multicolumn{2}{c}{ Kondisi Steady State awal } & \multicolumn{2}{c}{ Kondisi Steady State akhir } \\
\cline { 2 - 5 } & Mean & Standard Deviasi & Mean & Standard Deviasi \\
\hline 1 & 680 & 130 & 760 & 140 \\
2 & 1100 & 220 & 1260 & 240 \\
3 & 1220 & 280 & 1420 & 320 \\
4 & 380 & 50 & 490 & 60 \\
\hline
\end{tabular}

Tabel 7.

Perhitungan Dan Koefisien Heat Transfer Keseluruhan ( Kcal/h m2 oC) - Test B dan C.

\begin{tabular}{cccccc}
\multirow{2}{*}{ Efek } & \multirow{2}{*}{ Us } & \multicolumn{2}{c}{ Kondisi Steady State awal } & \multicolumn{2}{c}{ Kondisi Steady State akhir } \\
\cline { 3 - 6 } & & Mean & Standard Deviasi & Mean & Standard Deviasi \\
\hline 1 & 1960 & 630 & 80 & 630 & 130 \\
2 & 1370 & 1360 & 270 & 910 & 230 \\
3 & 820 & 1380 & 290 & 1310 & 430 \\
4 & 430 & 360 & 40 & 370 & 50 \\
\hline
\end{tabular}

Nilai $U$ diperoleh untuk efek pertama rendah, kurang dari setengah dari prediksi rumus Swedia (lihat Tabel 7, Uji B). Kondisi ini terjadi karena bagian evaporator sebagian dibanjiri uap terkondensasi dan, karena itu kapasitas penguapan menjadi berkurang. Nilai koefisien yang diperoleh untuk efek kedua dan keempat sesuai dengan prediksi formula, sedangkan untuk efek ketiga adalah lebih besar dari yang diharapkan tapi ini dibenarkan karena ada uap bleeding dalam unit ini .

Ketika fouling meningkat koefisien $U$ akan menurun, dalam hal ini koefisien $U$ yang dihitung ternyata tetap praktis konstan (signifikansi statistik pada kepercayaan 95\%) hal ini karena tingginya variabilitas dari koefisien menghilangkan pengaruh fouling pada nilai U. (Tabel 7).

\section{SIMPULAN}

Dari hasil penelitian ini menunjukkan bahwa uji $\mathrm{A}$ menunjukkan kesulitan praktis dalam menganalisis kondisi steady state dari peralatan evaporator karena adanya interaksi yang kuat dengan peralatan lainnya. Untuk perhitungan yang lebih tepat dari uap yang dikonsumsi dan arus uap yang dihasilkan dalam setiap efek, data pengamatan yang akurat terkait aliran dan konsentrasi feed (nira jernih) yang masuk efek pertama diperlukan.

Nilai koefisien perpindahan panas dalam efek pertama berbeda terutama dari yang diharapkan. Hal ini dapat disebabkan adanya masalah operasional pada stasiun penguapan. Estimasi nilai untuk koefisien perpindahan panas $(U)$ menunjukkan dispersi dispersi tinggi. Akurasi dapat ditingkatkan jika 
jika temperatur transmitter ditempatkan jauh dari permukkan nira dalam evaporator.

Proses maintenance secara rutin dan berkualitas akan meningkatkan performance dari stasiun penguapan, yang pada akhirnya akan meningkatkan efisiensi penggunaan energy pada stasiun penguapan khususnya dan secara berantai akan meningkatkan efisiensi proses keseluruhan.
Notasi :

B : Fraksi padatan dalam nira jernih dan nira kental ( ${ }^{\circ}$ Brix:- $\%$ berat)

E : Aliran uap yang keluar dari efek ( evaporator)

$f \quad$ : Fungsi Vector

F : Laju alir nira jernih dan nira kental (ton/jam)

$\mathrm{T}$ : Temperatur nira jernih dan nira kental $\left({ }^{\circ} \mathrm{C}\right)$

Tc : Temperatur barometric condenser

Tv : Temperatur uap $\left({ }^{\circ} \mathrm{C}\right)$

$U$ : Heat-transfer coefficient keseluruhan hasil perhitungan $\left(\mathrm{Kcal} / \mathrm{h} \mathrm{m}{ }^{\circ} \mathrm{C}\right)$

Us : Heat-transfer coefficient keseluruhan dari persamaan $(4)\left(\mathrm{Kcal} / \mathrm{h} \mathrm{m} 2{ }^{\circ} \mathrm{C}\right)$

$\mathrm{V}$ : Aliran uap / steam

var: Variance

$x$ : Input vector dari variabel dan parameter:

s : Standard deviasi

w : Kontribusi Fraksional ke variabilitas keseluruhan

\section{UCAPAN TERIMA KASIH}

Terima Kasih disampaikan kepada seluruh Tim kegiatan FEED pabrik gula Merah Putih, atas kerjasama yang baik yang sudah diberikan.

\section{DAFTAR PUSTAKA :}

1. E Hugot, Hand book of Cane sugar Engineering, (1986)

2. Mah, R., Chemical Process Structures and Information Flows, Butterworths, Boston, UK. (1990)

3. Smith, I. and L. Taylor, .Some Data on Heat Transfer in Multiple Effect Evaporators., Proc. Of The South African Sugar Tech. Association, 51-55 (1981).

4. ........................ Data operasi PG Semboro, 2012

5. S.Feyo de Azevedo, A. Rodrigues, A.P. Wardle On the optimization of tubular fixed-bed catalytic reactors, Pages 9-16 